\title{
The Biochemical Composition and Energy Content of Arctic Marine Macrozooplankton
}

\author{
J.A. PERCY ${ }^{1}$ and F.J. FIFE ${ }^{1}$
}

\begin{abstract}
Protein, lipid, carbohydrate, water, ash and caloric energy contents during the open water season of 14 species of macrozooplankton and four epibenthic amphipods common to the inshore waters of southern Baffin Island are compared. The highest energy content occurred in euphausiids and hyperiid amphipods and the lowest in ctenophores and cnidarians. Lipid appeared to be an important energy reserve in most of the species examined, while carbohydrate concentrations were consistently low. In four dominant species (Mertensia ovum, Parathemisto libellula, Sagitta elegans and Thysanoessa inermis) there was evidence of a progressive increase in lipid and caloric energy content during the course of the summer. Similarities and differences in biochemical composition and energy content of zooplankton from the Arctic and other marine areas are briefly discussed.
\end{abstract}

Key words: arctic zooplankton, marine, biochemical composition, calories, energy content

RÉSUMÉ. Les teneurs en protéines, lipides, hydrates de carbone, eau et cendre, et le contenu en énergie calorique de 14 espèce planctoniques et quatre amphipodes benthiques, qui se trouvent en abondance dans l'eau côtière au sud de l'île de Baffin, sont comparées. Les plus grandes quantités d'énergie se trouvent dans les euphausiacées et les amphipodes planctoniques (hyperiids), et les moindres dans les cténaires et les cnidaires. Il semble que les lipides soient une réserve importante d'énergie dans la plupart des espèces étudiées, tandis que la concentration d'hydrates de carbone est, sans exception, très faible. Dans les quatres espèces dominantes (Mertensia ovum, Parathemisto libellula, Sagitta elegans et Thysanoessa inermis) il y avait une augmentation graduée des quantités de lipides et d'énergie calorique pendant l'été. Les similarités et les différences dans la composition biochimique et dans le contenu énergétique entre les animaux planctoniques arctiques et ceux d'autres régions marines sont discutées brièvement.

Traduit par les auteurs.

\section{INTRODUCTION}

Polar marine ecosystems are of considerable interest from an energetics viewpoint. In recent years much attention has been devoted to describing the basic organization and to measuring rates of fundamental processes. One of their most important features is the extremely abbreviated but intense annual pulse of phytoplankton growth. These pronounced seasonal oscillations in primary production of organic matter undoubtedly have a far-reaching influence on many of the physiological processes associated with secondary production in marine animals. However, our knowledge of the dynamics of secondary production in polar seas is limited and it is not yet possible to define the nature and magnitude of the compensatory adjustments employed by different groups of organisms. It appears likely, however, that seasonal accumulation of energy reserves will figure prominently among the various strategies utilized.

Information on the organic composition and energy content of the various species is an important element in our understanding of the distribution, seasonal variations and complex interchange in matter and energy within any ecological community. It is not surprising therefore that studies have been conducted on the biochemical composition and caloric content of a wide range of marine species. The overwhelming majority of such studies have involved temperate and tropical species. Relatively few have dealt with the biochemical composition of Antarctic (Littlepage, 1964; Ferguson and Raymont, 1974; Clarke, 1980) or arctic (Ikeda, 1972; Lee, 1974, 1975; Bamstedt, 1978; FalkPetersen, 1981) zooplankton, and even fewer have provided information on their caloric energy content.
In conjunction with studies on the energetics of several key arctic macrozooplankton carnivores we have gathered data on the biochemical composition and energy content of a number of macrozooplanktonic and several epibenthic species common in southern Baffin Island waters. The information is summarized here in view of its potential utility in other trophodynamic studies involving the arctic marine ecosystem.

\section{METHODS}

Animals were collected with a $1 \mathrm{~m}$ conical net with approximately $1 \mathrm{~mm}$ mesh, at irregular intervals during two consecutive open water seasons (August-September) in upper Frobisher Bay (Station 5 of Grainger, 1971; $63^{\circ} 40.2^{\prime} \mathrm{N}, 68^{\circ} 26.3^{\prime} \mathrm{W}$ ). A total of 14 different zooplankton species were analyzed. The polychaetes were not identified to species, and may include a mixture of Autolytus alexandri, A. cornutus and A. prismaticus. Four common epibenthic amphipods were also included in the analysis; Anonyx nugax and Orchomonella minuta were collected in traps in $\mathbf{2 0} \mathrm{m}$ of water and Onisimus litoralis and Gammarus setosus were collected intertidally.

Live animals were transported to the laboratory and sorted to species. Samples were rinsed with isotonic ammonium formate, drained for two minutes on plankton netting over vacuum (except for gelatinous forms), weighed and lyophilized. In a few instances small quantities of material collected over several days were frozen and then pooled for lyophilization. Samples were stored in a freezer until analyzed, usually within nine months of collecting.

\footnotetext{
${ }^{1}$ Arctic Biological Station, Department of Fisheries and Oceans, 555 St. Pierre Boulevard, Ste. Anne de Bellevue, Quebec, Canada H9X 3R4
} 
Prior to analysis the samples were brought to constant weight at $70^{\circ} \mathrm{C}$ and cooled in a dessicator. After weighing, tissues were finely ground, mixed thoroughly and subsamples taken for analysis.

Only compounds of potential nutritional significance (protein, lipid and carbohydrate) or those required for interconversions among different biomass expressions (water content, ash content) were measured.

Protein was measured spectrophotometrically by the Biuret method following the procedure of Bamstedt (1974). Samples of 5-10 mg were analyzed and bovine albumin was used as a standard.

Lipid was estimated gravimetrically following extraction of 50-100 mg samples with chloroform-Methanol (2:1) in a microsoxhlet extraction apparatus. The crude lipid extract was washed with $0.9 \% \mathrm{NaCl}$ solution to remove non-lipid contaminants (Folch et al., 1957). The solvent was evaporated at $70^{\circ} \mathrm{C}$ and the residue held in a dessicator overnight prior to weighing.

Carbohydrate was measured spectrophotometrically by the anthrone method, essentially as described by Dowgiallo (1975), following digestion of $10-20 \mathrm{mg}$ samples in hot $10 \%$ trichloro acetic acid.

Ash content was estimated by incinerating $30-60 \mathrm{mg}$ samples at $500^{\circ} \mathrm{C}$ for $4 \mathrm{~h}$ and determining weight loss.
Caloric content of pelletized 5-20 mg samples was determined with a Phillipson microbomb calorimeter (Phillipson, 1964) employing standard procedures. With certain tissues having a very high inorganic content (such as ctenophores and hydromedusae) it was necessary to add $10-30 \%$ benzoic acid to ensure complete ignition. Caloric content is expressed both as calories/mg dry weight and calories/mg ash free dry weight.

\section{RESULTS AND DISCUSSION}

A summary of the biochemical composition of all species analyzed is presented in Table 1 . Few were available in adequate quantities during the whole open water season, so except in four cases no attempt has been made to demonstrate patterns of increase or decrease of specific components with time. The results presented in Table 1 are the maximum and minimum mean values obtained from all of the collections analyzed. The results are thus indicative of variations in composition observed during the open water season, but do not necessarily reflect seasonal maxima or minima for the various components in each of the species. Detailed tabulations of biochemical and caloric data obtained for individual collections along with sup-

TABLE 1. Biochemical composition of macrozooplankton and epibenthic amphipods from Frobisher Bay during the open water season

\begin{tabular}{|c|c|c|c|c|c|}
\hline \multirow{2}{*}{ Species } & \multicolumn{5}{|c|}{ Composition (percent) ${ }^{1}$} \\
\hline & Water & Protein & Lipid & Carbohydrate & Ash \\
\hline \multicolumn{6}{|l|}{ Cnidaria: } \\
\hline Bougainvillia superciliaris & $95.8(7)^{2}$ & $7.7-14.9(12)$ & $6.8-10.0(17)$ & $0.7-1.0(14)$ & $56.1-66.0(7)$ \\
\hline Halitholus cirratus & $95.7-96.0(6)$ & $10.4-18.2(18)$ & $4.6-7.6(15)$ & $0.7-0.8(6)$ & $53.4-66.6(3)$ \\
\hline Sarsia princeps & $95.6(3)$ & $14.5-14.7(10)$ & $7.8-9.1(12)$ & $0.4-0.8(11)$ & $61.8-64.7(3)$ \\
\hline Hybocodon prolifer & $94.9(1)$ & $23.0-31.0(3)$ & $13.1-22.1(2)$ & $0.8(2)$ & $44.8-46.0(2)$ \\
\hline Aglantha digitale & $95.6(5)$ & $21.6-22.1(20)$ & $6.0-6.9(17)$ & $0.4-0.9(9)$ & $57.1-59.8(6)$ \\
\hline \multicolumn{6}{|l|}{ Ctenophora: } \\
\hline Mertensia ovum & $94.9-96.0(15)$ & $19.9-23.8(21)$ & $5.3-14.4(24)$ & $0.5-0.7(21)$ & $53.1-59.3(19)$ \\
\hline Beroe cucumis & $96.2-97.1(3)$ & $8.7-8.8(10)$ & $4.4-6.0(9)$ & $0.6-0.7(8)$ & $63.3-69.5(5)$ \\
\hline \multicolumn{6}{|l|}{ Polychaeta: } \\
\hline Autolytus spp. & $85.9-88.9(2)$ & $70.7-78.8(9)$ & $16.7-22.2(7)$ & $4.2-5.1(4)$ & $14.4-18.0(3)$ \\
\hline \multicolumn{6}{|l|}{ Gastropoda: } \\
\hline Spiratella helicina & $73.9-78.6(2)$ & $70.1-77.0(5)$ & $18.3-19.1(4)$ & $2.5(2)$ & $23.5-23.6(2)$ \\
\hline Clione limacina & $92.1-94.3(9)$ & $39.2-40.1(20)$ & $17.0-24.4(15)$ & $0.6-1.0(21)$ & $35.5-40.9(6)$ \\
\hline \multicolumn{6}{|l|}{ Amphipoda: } \\
\hline Parathemisto libellula & $75.8-79.3(12)$ & $36.4-58.6(36)$ & $18.2-34.6(21)$ & $1.0-1.5(20)$ & $15.2-20.7(10)$ \\
\hline Hyperoche medusarum & $75.9-83.8(4)$ & $35.9(2)$ & $27.2(2)$ & $2.9(1)$ & $12.5-17.0(3)$ \\
\hline Onisimus litoralis ${ }^{3}$ & $72.8-75.1(4)$ & $44.3(6)$ & $21.5(5)$ & $2.9(7)$ & $26.9-30.5(6)$ \\
\hline Gammarus setosus $^{3}$ & $73.2-79.5(28)$ & $41.2-53.7(27)$ & $7.3-14.3(27)$ & $2.1-3.0(21)$ & $22.9-30.4(23)$ \\
\hline Orchomonella minuta ${ }^{3}$ & - & $32.1(7)$ & $15.0(5)$ & $4.5(7)$ & $36.4(3)$ \\
\hline Anonyx nugax ${ }^{3}$ & $73.0(4)$ & $35.9-41.1(13)$ & $18.4-25.6(16)$ & $1.5-1.8(13)$ & $24.9-31.3(9)$ \\
\hline \multicolumn{6}{|l|}{ Euphausiacea: } \\
\hline Thysanoessa inermis & $68.2-79.6(4)$ & $43.9(7)$ & $52.4(5)$ & $0.3(7)$ & $5.9-7.4(5)$ \\
\hline \multicolumn{6}{|l|}{ Chaetognatha: } \\
\hline Sagitta elegans & $90.1-90.5(21)$ & $56.8-69.8(20)$ & $17.6-23.9(15)$ & $0.03-0.1(13)$ & $15.6-20.7(12)$ \\
\hline
\end{tabular}

\footnotetext{
'Expressed as percent of dry weight, except for water content which is expressed as percent of live weight.

${ }^{2}$ Total number of samples indicated in parentheses.

${ }^{3}$ Epibenthic species.
} 
porting statistical information are available in a data report format (Percy and Fife, 1980).

\section{Water Content}

The water content of crustaceans was lowest, ranging from 68 to $84 \%$ of live weight. There was no evidence of a consistent difference between epibenthic and planktonic amphipods. Relatively soft-bodied forms such as Autolytus sp., Clione limacina and Sagitta elegans had water contents that ranged from 85.9-94.3\%. As expected gelatinous ctenophores and cnidarians had exceptionally high water contents ranging from 94.9 to $97.1 \%$ of body weight. Such values are comparable to those found for several cnidarians and ctenophores (95.0-99.1\%) by Curl (1962) and for Aglantha digitale (94.2\%) from the Bering Sea (Ikeda, 1972). Reeve and Walter (1978), reviewing the available information, concluded that the water content of ctenophores from temperate and tropical areas generally ranged from 95.0 to $\mathbf{9 6 . 6 \%}$. There is no evidence that polar species are significantly different.

\section{Protein Content}

The amount of protein varied markedly among the different groups. Highest values were found in Spiratella helicina (70.1-77.0\%) and the polychaete Autolytus spp. (70.7-78.8\%). Ikeda (1972) reported an equally high value (73.8\%) for another species of planktonic polychaete (Tomopteris septentrionalis) from the Bering Sea. The protein content of Sagitta elegans was also high (56.8$69.8 \%$ ), although considerably lower than the $84 \%$ reported for this species in the Bering Sea (Ikeda, 1972). Our estimate is comparable to that found for Sagitta elegans $(54.2 \%)$ in Nova Scotian waters in November (Mayzaud and Martin, 1975). Large seasonal fluctuations in protein may occur in chaetognaths. Reeve et al. (1970) found that the protein content of Sagitta hispida varied from 39 to $70 \%$ during the course of the year, with a mean value of $52.9 \%$.

Amphipods were intermediate in protein content, with values ranging from 32.1 to $58.6 \%$. There was no indication of a consistent difference between planktonic and epibenthic forms. Ikeda's (1972) value for Euthemisto (= Parathemisto) libellula (49.4\%) lies close to the mid-point of the range (36.4-58.6\%) found in the present study. Nakai (1955) reported a protein content of $48.7 \%$ for Parathemisto sp. in Japanese waters.

The protein content of the euphausiid Thysanoessa inermis in September (43.9\%) was similar to that of amphipods. In Norwegian waters the protein content of adult $T$. inermis ranged from about 35 to 53 during the year, with the highest values occurring in spring and again in autumn (Falk-Petersen, 1981). These estimates are considerably lower than that found for Thysanoessa raschii (78.6\%) in the Bering Sea (Ikeda, 1972) and slightly lower than that of Meganyctiphanes norvegica (51-64\%) from the North Atlantic (Raymont et al., 1971). The apparent low protein value for $T$. inermis may reflect the unusually high lipid content of this species, in view of the fact that the results are expressed as proportions rather than absolute amounts.

The lowest protein values were found among cnidarians and ctenophores (7.7-23.8\%). However, Hybocodon prolifer had concentrations much higher (23.0-31.0\%) than that of other gelatinous species. Ikeda (1972) reported a protein content of $56.5 \%$ for Aglantha digitale from the Bering Sea, a value that is more than double that found in the present study (21.6-22.1\%).

\section{Lipid Content}

The lipid content differed considerably among the various groups, and more importantly from an energetics viewpoint, fluctuated greatly during the open water season in certain species. The observed changes in lipid content and their possible significance are discussed more fully below.

The highest lipid content was found in the euphausiid $T$. inermis, whose dry tissue was more than half ( $54.2 \%)$ lipid. This is unusually high in comparison to values reported for other euphausiids. These generally range from 2.7 to $36 \%$ of dry weight (Nakai, 1955; Littlepage, 1964; Mauchline and Fisher, 1969; Raymont et al., 1971; Ferguson and Raymont, 1974; Bamstedt, 1976), with the greatest values usually associated with species from higher latitudes. Mauchline and Fisher (1969), reviewing the available data, tentatively concluded that "it is probably true that euphausiids from high latitudes tend to accumulate greater reserves of lipids than those in lower latitudes." However, Thysanoessa raschii from the Bering Sea had a lipid content of only $7.2 \%$ of dry weight (Ikeda, 1972), far below that found here for $T$. inermis. Confirmation of the high lipid content of Thysanoessa inermis is provided by FalkPetersen (1981) who found that in Norwegian waters the lipid content of adults varied from approximately 36 to $52 \%$ during the year, with the highest values occurring in late summer and autumn, approximately the time of our collection (19-20 September).

Planktonic hyperiid amphipods generally had a higher lipid content (18-35\%) than did epibenthic gammarid amphipods $(7-22 \%)$. It is likely that in polar seas seasonal fluctuations in food are less pronounced in benthic than in planktonic habitats. Benthic amphipods, at least, do not appear to be dependent on extensive lipid reserves for winter survival (Percy, 1979). In comparing our results with the limited data already available we find no evidence of an increase in lipid content of the hyperiids with increasing latitude as appears to occur in the euphausiids. Parathemisto sp. from Japan had a lipid content of $39.6 \%$ (Nakai, 1955) which is even higher than the maximum found in the present study. Our early summer values (18.2\%) are comparable to the $21.6 \%$ reported for $P$. libellula in the Bering Sea in June (Ikeda, 1972), and the total range (18.2-34.6\%) is essentially similar to that found in $P$. abyssorum (19-32\%) from the Arctic Ocean (Lee, 1975). 
Our estimate of the lipid content of Clione limacina $(17.0-24.4 \%)$ is comparable to that found by Ikeda (1972) for animals from the Bering Sea (17.5\%) and by Lee (1975) from the Arctic Ocean (19\%).

The chaetognath $S$. elegans also had a relatively large lipid content, ranging from 17.6-23.9\% of dry weight. The lipid content of $S$. hispida varied during the year from 9-27\%, with an overall mean of $17.0 \%$ (Reeve et al., 1970). Lee (1975) found 19\% lipid in Eukrohnia hamata from the Arctic Ocean, while Ikeda (1972) found an unusually low lipid content of only $6.7 \%$ in S. elegans from the Bering Sea in early summer.

Generally, the cnidarians had a low lipid level, ranging from 4.6-10.0\%. The one notable exception was Hybocodon prolifer (13.1-22.1\%). Although these latter values are based on a smaller number of samples, they appear reasonable in view of the fact that the caloric and organic content of this species is also unusually high. Ikeda (1972) reported a lipid content of $3 \%$ for Aglantha digitale from the Bering Sea in early summer. Our estimate is twice as great, but involves animals collected later in the summer.

\section{Carbohydrate Content}

Carbohydrate was a minor component in all species examined. It ranged from 0.4 to $5.1 \%$ of dry weight. Ikeda (1972) reported comparable concentrations $(0.5-3.1 \%)$ in a variety of planktonic animals from the Bering Sea. In the Sargasso Sea carbohydrate levels in zooplankton ranged from 0.16 to $1.45 \%$ of dry weight (Beers, 1966), slightly lower than values observed in arctic forms. The lowest concentration occurred in Sagitta elegans $(0.03-0.1 \%)$. This is comparable to the $0.7 \%$ reported for this species in the Bering Sea (Ikeda, 1972). In Nova Scotia waters levels of $1.5 \%$ of dry weight have been found in this species (Mayzaud and Martin, 1975). The ctenophores and cnidarians all contained less than $1 \%$ carbohydrate. The values are comparable to those reported for the ctenophore Pleurobrachia pileus $(<0.025-1.4 \%$ of dry weight) by Raymont and Krishnaswamy (1960). Amphipods had generally higher levels (1.0-4.5\%) than most of the gelatinous forms. The highest concentration occurred in the pelagic polychaetes, Autolytus spp. (4.2-5.1\%). In the Bering Sea the highest concentrations were found in amphipods and polychaetes and the lowest in pteropods, euphausiids and chaetognaths (Ikeda, 1972), a finding generally consistent with the present results. Beers (1966) also concluded that forms with high water content such as hydromedusae and chaetognaths had the lowest carbohydrate content.

Our results support the conclusion of Raymont and Conover (1961) that the carbohydrate content of planktonic animals is usually low and does not appear to represent a significant nutritional reserve.

\section{Ash Content}

As anticipated, cnidarians and ctenophores exhibited the highest ash content (44.9-69.9\%) of all organisms analyzed. Most of this inorganic residue is no doubt attribut- able to the salt content of the large volume of seawater that constitutes the bulk of the animals' tissue. The range of values found is comparable to that reported by Curl (1962) for these groups (49.1-75.0\%) in the North Atlantic. Ikeda (1972) reported a considerably lower ash value $(39.2 \%)$ in Aglantha digitale than that obtained in the present study (57.1-59.8\%). The ash content (74\%) of the tentaculate ctenophore Pleurobrachia bachei (Hirota, 1972) was much greater than that of Mertensia ovum (53.1-59.3\%).

Ash content of pelagic amphipods (12.5-20.7\%) was consistently lower than that of epibenthic species $(22.9$ $-36.4 \%)$. These latter values are comparable to the seasonal range (21.3-27.2\%) observed in another arctic epibenthic amphipod (Percy, 1979). This difference between the two groups probably reflects the presence of a lighter, less heavily calcified exoskeleton in the planktonic species for whom relative density is an important energetic consideration. Omori (1969) reported a mean ash content of $20.4 \%$ for several north Pacific planktonic amphipods, as well as a value of $13.4 \%$ for Parathemisto japonica. Euthemisto ( = parathemisto) libellula in the Bering Sea was found to have an ash content of $21.1 \%$, reasonably close to the upper end of the range found in the present study (15.2-20.7\%). These values are all considerably higher than the 7.7-10.1\% ash content reported for Euthemisto sp. (Parathemisto?) by Phillipson (1964).

The lowest ash content was found in the euphausiid, Thysanoessa inermis (5.9-7.4\%) which agrees closely with the mean value of $8.2 \%$ found for several north Pacific euphausiids (Omori, 1969), 7.1\% for Euphausia pacifica (Nakai, 1955) and 6.0-10.8\% for Euphausia krohnii (Phillipson, 1964), but is lower than the 9-17\% ash reported for $T$. inermis in Norwegian waters (Falk-Petersen, 1981). Thysanoessa raschii from the Bering Sea also had a somewhat higher (10.9\%) ash content (Ikeda, 1972), as did Meganyctiphanes norvegica (14.7-17.3\%: Phillipson, 1964).

The ash content of Sagitta elegans (15.6-20.7\%) is higher than that reported by Ikeda (1972) for animals from the Bering Sea $(8.0 \%)$ and considerably higher than the mean value of $4.8 \%$ for this species from the North Pacific (Omori, 1969). Mayzaud and Martin (1975) found an ash content of $6.7 \%$ in $S$. elegans in Nova Scotia waters. Interestingly enough, when this data for $S$. elegans is considered in terms of latitude of collection there is a consistent increase in inorganic content with increasing latitude. Whether or not this represents an influence of habitat temperature and its possible physiological significance remains to be demonstrated. The only values for ash content of a chaetognath that are comparable to ours are those of Bamstedt (1978) who found a mean value of $18.3 \%$ (annual range of 14-21\%) for Eukrohnia hamata in Norwegian waters.

\section{Caloric Content}

In order to permit comparison with available information, caloric values in Table 2 are expressed in terms of 
TABLE 2. The organic and energy content of macrozooplankton and epibenthic amphipods from Frobisher Bay

\begin{tabular}{|c|c|c|c|}
\hline Species & $\begin{array}{c}\text { Organic } \\
\text { content }(\%)^{t}\end{array}$ & $\begin{array}{c}\text { Calories/ } \\
\text { mg dry weight }\end{array}$ & $\begin{array}{l}\text { Calories/ } \\
\text { mg ash free } \\
\text { dry weight }\end{array}$ \\
\hline \multicolumn{4}{|l|}{$\begin{array}{l}\text { Cnidaria: } \\
\quad \text { Bougainvillia }\end{array}$} \\
\hline superciliaris & $32.3-36.7$ & $1.96-2.12(9)^{2}$ & $5.78-6.06$ \\
\hline Halitholus cirratus & $33.4-43.4$ & $2.00-2.43(9)$ & $5.60-5.99$ \\
\hline Sarsia princeps & $35.3-37.0$ & $1.17-1.60(10)$ & $3.32-4.32$ \\
\hline Hybocodon prolifer & $54.1-55.2$ & $2.81-3.99(8)$ & $5.20-7.22$ \\
\hline Aglantha digitale & $40.1-42.9$ & $1.95-2.03(9)$ & $4.74-5.04$ \\
\hline \multicolumn{4}{|l|}{ Ctenophora: } \\
\hline Mertensia ovum & $40.7-47.0$ & $1.91-1.93(11)$ & $4.16-4.70$ \\
\hline Beroe cucumis & $30.8-36.7$ & $1.04-1.68(9)$ & $3.13-4.58$ \\
\hline \multicolumn{4}{|l|}{ Polychaeta: } \\
\hline Autolytus spp. & $82.0-85.6$ & $4.46-5.04(9)$ & $5.44-5.89$ \\
\hline \multicolumn{4}{|l|}{ Gastropoda: } \\
\hline Spiratella helicina & $76.4-76.5$ & $3.69-4.20(9)$ & $4.83-5.49$ \\
\hline Clione limacina & $59.1-62.7$ & $3.31-4.05(10)$ & $5.60-6.46$ \\
\hline \multicolumn{4}{|l|}{ Amphipoda: } \\
\hline Parathemisto libellula & $79.7-84.8$ & $4.22-5.62(22)$ & $5.20-6.63$ \\
\hline Hyperoche medusarum & $83.0-87.5$ & $5.16-5.68(6)$ & $6.20-6.49$ \\
\hline Onisimus litoralis $^{3}$ & 73.1 & $4.39(6)$ & 6.01 \\
\hline Gammarus setosus $^{3}$ & $69.7-77.1$ & $3.93-4.38(21)$ & $5.52-5.68$ \\
\hline Orchomonella minuta ${ }^{3}$ & 63.6 & $3.54(6)$ & 5.57 \\
\hline Anonyx nugax ${ }^{3}$ & $68.7-75.1$ & $3.98-4.81(18)$ & $5.80-6.40$ \\
\hline \multicolumn{4}{|l|}{ Euphausiacea: } \\
\hline Thysanoessa inermis & $92.6-94.1$ & $5.80-6.21(8)$ & $6.26-6.60$ \\
\hline \multicolumn{4}{|l|}{ Chaetognatha: } \\
\hline Sagitta elegans & $79.3-84.4$ & $4.84-5.23(17)$ & $5.82-6.60$ \\
\hline
\end{tabular}

'Percent of dry weight.

${ }^{2}$ Total number of samples indicated in parentheses.

${ }^{3}$ Epibenthic species.

both dry weight and ash free dry weight. From a trophodynamic point of view the former is probably the more useful because it provides a measure of the relative energy value to the consumer of a given mass of food.

Because of the wide range in inorganic content of the organisms the caloric content expressed on a dry weight basis varies markedly. Highest values occurred in species having low ash and high lipid content such as euphausiids and hyperiid amphipods. The values found for Thysanoessa inermis $(5.80-6.21 \mathrm{cal} / \mathrm{mg}$ dry weight; $6.26-6.60 \mathrm{cal} / \mathrm{mg}$ ash free weight) are considerably higher than those reported for other euphausiid species. Phillipson (1964) reported values for Meganyctiphanes norvegica of $5.230 \mathrm{cal} / \mathrm{mg}$ ash free weight and for Euphausia krohnii of $5.25 \mathrm{cal} / \mathrm{mg}$ ash free weight, while Small (1967) obtained values of 4.28$5.16 \mathrm{cal} / \mathrm{mg}$ dry weight for Euphausia pacifica. The high caloric content observed in Thysanoessa inermis is clearly a reflection of the unusually high lipid content of this species. Similarly, the high caloric content of Parathemisto libellula $(4.22-5.62 \mathrm{cal} / \mathrm{mg}$ dry weight $5.20-6.63 \mathrm{cal} / \mathrm{mg}$ ash free weight) is also associated with a high lipid content. Williams and Robins (1979) reported a slightly lower caloric value $(5.138 \mathrm{cal} / \mathrm{mg}$ ash free dry weight) for the north Atlantic Parathemisto gaudichaudi. Our results are, however, comparable to the $5.515 \mathrm{cal} / \mathrm{mg}$ ash free weight found in Euthemisto sp. (Parathemisto?) by Phillipson (1964). The caloric content of epibenthic amphipods $(3.54-4.81 \mathrm{cal} / \mathrm{mg}$ dry weight) is considerably lower than that of pelagic hyperiids $(4.22-5.68 \mathrm{cal} / \mathrm{mg}$ dry weight), consistent with the observed differences in lipid and ash content. Epibenthic amphipods from North Carolina had a caloric content $(2.909-4.397 \mathrm{cal} / \mathrm{mg}$ dry weight) somewhat lower than that found in the present study (Thayer et al., 1973).

Cnidarians and ctenophores generally had a very low caloric content ranging from 1.04 to $2.43 \mathrm{cal} / \mathrm{mg}$ dry weight. One notable exception was Hybocodon prolifer with a caloric content of $2.81-3.99 \mathrm{cal} / \mathrm{mg}$ dry weight. This high energy content clearly reflects the unusually high lipid and protein content of this species. Values for the energy content of ctenophores $(1.04-1.93 \mathrm{cal} / \mathrm{mg}$ dry weight) are comparable to those of Thayer et al. (1973) who found that mixed ctenophores from North Carolina had an energy content of $0.65-2.18 \mathrm{cal} / \mathrm{mg}$ dry weight. In terms of ash free dry weight the caloric content of most of the gelatinous forms does not differ dramatically from that of the other planktonic forms examined.

\section{Variations in Lipid and Caloric Content}

Only four species were obtained in sufficient quantity in several collections to warrant some preliminary consideration of trends in biochemical composition and energy content during the course of the relatively brief open water

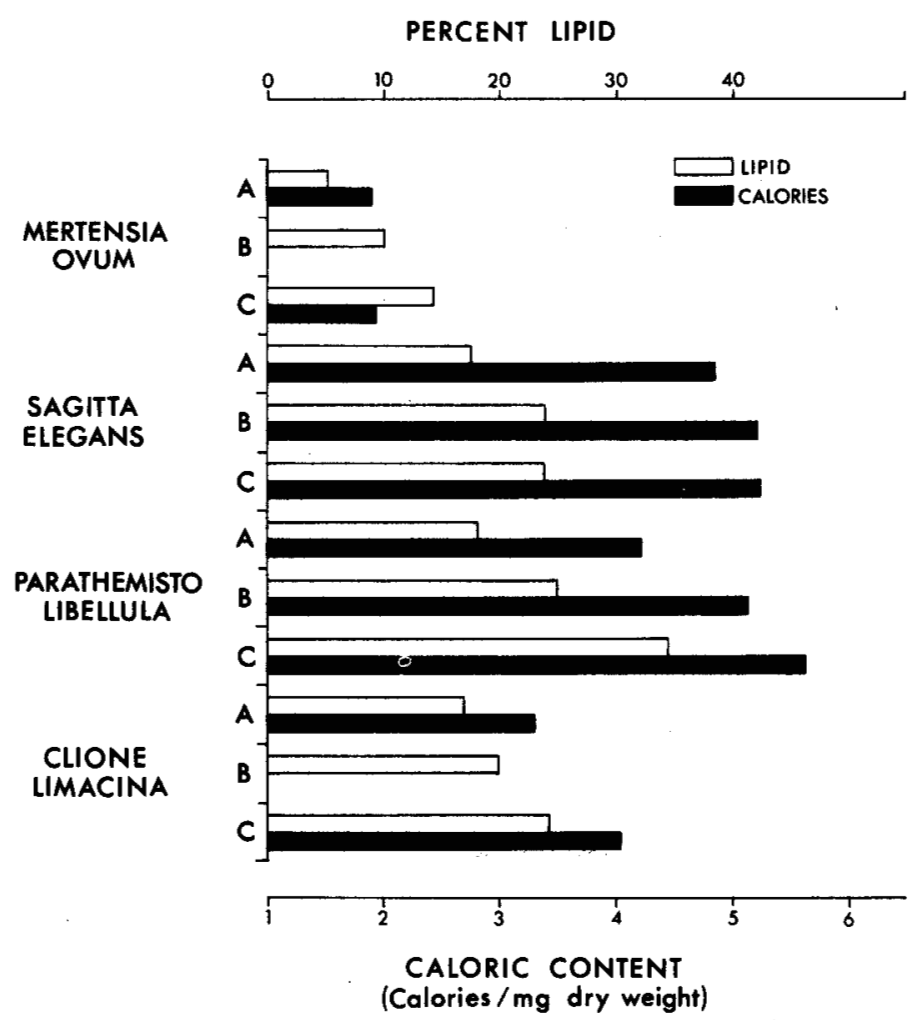

FIG. 1. The lipid and caloric energy contents of four dominant macrozooplankton species at different times during the open water season (A: July 27-August 9, B: August 11-29 and C: September 19-20). 
season. Unfortunately it has not yet proven feasible to collect adequate quantities of macrozooplankton during periods of the year when ice cover is present, so the magnitude and precise pattern of the annual energy cycle is still uncertain.

It is generally agreed that lipid serves as the principal nutritional reserve of most zooplankton species. Some polar forms store large amounts of lipid during the summer (Littlepage, 1964; Lee, 1975). Figure 1 illustrates the changes in lipid and caloric energy content occurring in the four species between late July and late September. In all cases, both lipid and caloric energy content rise as the season progresses. It should be emphasized that the earliest samples were collected some weeks after initiation of the dramatic rise in biomass of herbivorous microzooplankton, which characteristically begins during June and early July and peaks in early August (Grainger, 1971). Thus the planktonic carnivores had been exposed to a gradually improving food regime for some time prior to the earliest collections. It is unlikely therefore that the early summer values reflect the nutritional status of the animals at the end of the winter period. Similarly, the microzooplankton biomass declines slowly during the autumn and only reaches a minimum in December (Grainger, 1971). Thus the energy content of the late summer collections may not represent the maximum level prior to the onset of winter. However, results for the lipid content of Parathemisto libellula, which range from 18.2 to $34.6 \%$ of dry weight over the course of the summer, are comparable to the levels found in Parathemisto abyssorum from the Arctic Ocean which ranged from $19 \%$ in February to $32 \%$ in November (Lee, 1975).

In this preliminary survey of the biochemical and energy content of a number of species no attempt was made to segregate the animals according to sex, reproductive status or body size. The results thus represent the average biochemical and energy content of a population at the time of collection. Detailed studies of some of the factors influencing biochemical composition of the ecologically dominant macrozooplankton species from coastal waters of southern Baffin Island are currently in progress.

\section{ACKNOWLEDGEMENTS}

We extend thanks to L. Bertrand, F. Paton and M. DeFeydeau for their capable assistance both in the field work and in the laboratory analyses. Much of the work was carried out in the Ikaluit Research Laboratory in Frobisher Bay, and for making space available in this establishment we are most grateful to $A$. Theriault and A. Pelletier of DIAND.

\section{REFERENCES}

BAMSTEDT, U. 1974. Biochemical studies on the deep-water pelagic community of Korsfjorden, western Norway: Methodology and sample design. Sarsia 56:71-86.

1976. Studies on the deep-water pelagic community of Korsfjorden, western Norway: Changes in the size and biochemical composition of Meganycitiphanes (sic) norvegica (Euphausiacea) in relation to its life cycle. Sarsia 61:15-30.

1978. Studies on the deep-water pelagic community of Korsfjorden, western Norway: Seasonal variation in weight and biochemical composition of Chiridius armatus (Copepoda), Boreomysis arctica (Mysidacea), and Eukrohnia hamata (Chaetognatha) in relation to their biology. Sarsia 63:145-154.

BEERS, J.R. 1966. Studies on the chemical composition of the major zooplankton groups in the Sargasso Sea off Bermuda. Limnology and Oceanography 11:520-528.

CLARKE, A. 1980. The biochemical composition of krill, Euphausia superba Dana, from South Georgia. Journal of Experimental Marine Biology and Ecology 43(3):221-236.

CURL, H., Jr. 1962. Standing crops of carbon, nitrogen, and phosphorus and transfer between trophic levels in continental shelf waters south of New York. Rapports et Procès-Verbaux des Reunions, Conseil Permanent International pour l'Exploration de la Mer 153:183-189.

DOWGIALLO, A. 1975. Chemical composition of an animal's body and its food. In: Grodzinski, W., Klekowski, R.Z. and Duncan, A. (eds.). Methods for Ecological Bioenergetics. IBP Handbook No. 24. London: Blackwell. 160-199.

FALK-PETERSEN, S. 1981. Ecological investigations on the zooplankton community of Balsfjorden, northern Norway: Seasonal changes in body weight and the main biochemical composition of Thysanoessa inermis (Kroyer), T. raschii (M. Sars), and Meganyctiphanes norvegica (M. Sars) in relation to environmental factors. Journal of Experimental Marine Biology and Ecology 49:103-120.

FERGUSON, C.F. and RAYMONT, J.K.B. 1974. Biochemical studies on marine zooplankton XII. Further investigations on Euphausia superba Dana. Journal of the Marine Biological Association of the United Kingdom 54(3):719-725.

FOLCH, J., LEES, M. and SLOANE STANLEY, G.H. 1957. A simple method for the isolation and purification of total lipids from animal tissues. Journal of Biological Chemistry 226:497-509.

GRAINGER, E.H. 1971. Biological oceanographic observations in Frobisher Bay. II. Zooplankton data, 1967-1970. Fisheries Research Board of Canada Technical Report No. 266.61 p.

HIROTA, J. 1972. Laboratory culture and metabolism of the planktonic ctenophore, Pleurobrachia bachei A. Agassiz. In: Takenouti, A.Y. (ed.). Biological Oceanography of the Northern North Pacific Ocean. Tokyo: Idemitsu Shoten. 465-484.

IKEDA, T, 1972. Chemical composition and nutrition of zooplankton in the Bering Sea. In: Takenouti, A.Y. (ed.). Biological Oceanography of the Northern North Pacific Ocean. Tokyo: Idemitsu Shoten. 433-442.

LEE, R.F. 1975. Lipids of arctic zooplankton. Comparative Biochemistry and Physiology 51(3B):263-266.

LITTLEPAGE, J.L. 1964. Seasonal variation in lipid content of two Antarctic marine crustacea. In: Carrick, R., Holdgate, M. and Prévost, J. (eds.). Biologie Antarctique. Paris: Hermann. 463-470.

MAUCHLINE, S. and FISHER, L.R. 1969. The biology of euphausiids. Advances in Marine Biology 7:1-454.

MAYZAUD, P. and MARTIN, J.-L.M. 1975. Some aspects of the biochemical and mineral composition of marine plankton. Journal of Experimental Marine Biology and Ecology 17:297-310.

NAKAI, Z. 1955. The chemical composition, volume, weight, and size of the important marine plankton. Tokai Regional Fisheries Research Laboratory Special Publication No. 5:12-24.

OMORI, M. 1969. Weight and chemical composition of some important oceanic zooplankton in the North Pacific Ocean. Marine Biology $3(1): 4-10$

PERCY, J.A. 1979. Seasonal changes in organic composition and caloric content of an arctic marine amphipod, Onisimus (= Boeckosimus) 
affinis H.J. Hansen. Journal of Experimental Marine Biology and Ecology 40(2): 183-192.

and FIFE, F.J. 1980.The proximate composition and caloric content of arctic marine invertebrates from Frobisher Bay. Canadian Data Report of Fisheries and Aquatic Sciences No. 214: iv + 35 p.

PHILLIPSON, J. 1964. A miniature bomb calorimeter for small biological samples. Oikos 15(1):130-139.

RAYMONT, J.E.G. and CONOVER, R.J. 1961. Further investigations on the carbohydrate content of marine zooplankton. Limnology and Oceanography 6:154-164.

RAYMONT, J.E.G. and KRISHNASWAMY, S. 1960. Carbohydrates in some marine plankton animals. Journal of the Marine Biological Association of the United Kingdom 39(2):239-248.

RAYMONT, J.E.G., SRINIVASAGAM, R.T. and RAYMONT, J.K.B. 1971. Biochemical studies on marine zooplankton VIII. Further investigations on Meganyctiphanes norvegica (M. Sars). Deep Sea Research 18(12):1167-1178.
REEVE, M.R., RAYMONT, J.E.G. and RAYMONT, J.K.B. 1970. Seasonal biochemical composition and energy sources of Sagitta hispida. Marine Biology 6(4):357-364.

REEVE, M.R. and WALTER, M.A. 1978. Nutritional ecology of ctenophores - a review of recent research. Advances in Marine Biology 15:249-287.

SMALL, L.F. 1967. Energy flow in Euphausia pacifica. Nature, London 215:515-516.

THAYER, G.W., SCHAAF, W.E., ANGELOVIC, J.W. and LACROIX, M.W. 1973. Caloric measurements of some estuarine organisms. Fishery Bulletin U.S. 71(1):289-296.

WILLIAMS, R. and ROBINS, D. 1979. Calorific, ash, carbon and nitrogen content in relation to length and dry weight of Parathemisto gaudichaudi (Amphipoda: Hyperiidea) in the north east Atlantic Ocean. Marine Biology 52(3):247-252 